\title{
POLITICS AND UNIVERSITY ADMINISTRATION IN NIGERIA
}

\author{
Afolabi, Comfort Yemisi \\ Centre for Gender and Development Studies, \\ Ekiti State University, Ado-Ekiti, Nigeria \\ Ekundayo, Haastrup T. \\ Department of Educational Management, \\ Faculty of Education, \\ Ekiti State University, Ado-Ekiti, Nigeria \\ Ogbiye, Cornelius A. \\ Department of Social Science Education, \\ Faculty of Education, \\ Ekiti State University, Ado-Ekiti, Nigeria
}

\begin{abstract}
Education is a prerequisite for youths to attain quality job, adequate and acceptable achievement. Every political dispensation is expected to provide good and quality education in any state or country. However, it appears that this is not to be, especially in most African countries. Leaders who should focus on quality education of the masses seemed to attach little or no importance to education and this could have great consequences for administration of tertiary institutions. The number of times these institutions were closed down seemed to spell doom for the tertiary and university education sector. It is on the basis of this that this study examined how university administration fared during various political dispensations in Nigeria at any point in time. The study found out that politics had not impacted much on administration of universities in Nigeria. It was therefore recommended that the administration of universities or tertiary institutions should be given the adequate attention and support that they deserve from government at all times. It was also recommended that heads of universities and tertiary institutions should be neutral and stay clear of partisan politics before and during their appointments.
\end{abstract}

KEY WORDS: Politics, university, administration, funding, governance.

\section{INTRODUCTION}

The university is very important in the production of high level manpower and the development of national consciousness. It is a congregation of intellectuals, constantly reproducing and reinventing itself and generating advanced knowledge for improvement of the socio-economic and physical environment (ASUU, 2002). The university is the bedrock of national development and integration; a leading light and the beacon of scientific breakthroughs and technological development worldwide. The university represents the most vital aspect of the educational system because it is at this level that the future is made possible through a kind of researched knowledge generated and disseminated to the other members of the society. It is the highest level of scholastic activities that entails enormous financial outlay which is mainly provided by governments in Nigeria as a social responsibility. There has been a considerable expansion in the number of universities in Nigeria with an equal expansion in the number of industrial unions in 
the universities. The role of university education as an indispensable tool for personal and national development has resulted to mass demand for this level of education in recent times. Federal, States and individual have therefore been devoting a reasonable portion of their income and resources to the provision of education services.

However, Sanubi and Akpotu (2015) observed a worrisome disposition of Nigeria's educational system in terms of worsening commitments of stakeholders to the maintenance and expansion of existing facilities and inadequate funding of the sector by concerned authorities. This may adversely affect the nation's achievement of the vision 20:2020 despite the fact that education serves as the foundation of any form of national development. Ayodele, Obafemi and Ebong (2013) noted that in order to achieve the vision 20:2020, there is the need to empower the citizens of Nigerians through good education which is the substance of national growth. The National Universities Commission (NUC) Survey Report in 2011 showed that only 30\% of university students' population was able to have access to classrooms, lecture theatre, laboratories and other physical facilities. Education in Nigeria is bedeviled by various problems such as poor funding, poor classrooms, teaching aids, paucity of qualified lecturers and poor learning environments (Odia \& Omofonmwan, 2007). According to Yagboyaju and Akinola (2019), over the decades, there was a sustained argument that Nigeria like other states in Africa and developing world underperformed due to lack of capacity to deal with contemporary complexities of governance. Political leadership and governance in Nigeria have been by self-interest and other primordial considerations, which takes priority over that of the public. The nature and characters of the political leadership explained the Nigerian State's lack of capacity for effective governance.

According to Otuya and Okolo (2020), the university serves as a crucial platform that the society depends on for teaching and research. The universities were expected to create, inspire and move the society forward. They stressed the need for functional entrepreneurial universities to continually improve skill acquisition, resourcefulness and exchange of expertise between industries and the academics to enhance better technologies that promotes sustainable development. Odia and Odia (2020) opined that accessibility to university education represents a vital instrument as well as the economic growth and technological advancement of the citizens of a country. However, most of the candidates for Nigerian universities, were unable to gain admission to the university of their choices. In the same vein, Kazeem (2017) asserted that in Nigeria, only one out of four of those who apply for university admission got admitted. Furthermore, new data from Nigeria's National Bureau of Statistics (NBS) and the Joint Admissions and Matriculation Board (JAMB) indicated that from 2010-2015, out of 10 million applicants for admission into tertiary institutions, only $26 \%$ were admitted. This trend appears to continue till the present day.

Moreover, the way the administration of university education is being disrupted in the country during one political dispensation or the other is becoming alarming and very disturbing. Many courses had to be scrapped or students lumped together when one government succeeded another and had to run its own educational policies or programmes. A very good example is when three universities had to be collapsed together under one umbrella or name in Ekiti State in 2011. Again, during the 3rd civilian regime in Ekiti State, Faculty of Medicine that was established three years earlier was scrapped in University of Ado-Ekiti (UNAD) and the students studying medicine in the University were moved to Obafemi Awolowo University, Ile-Ife. Many university vice-chancellors were replaced according to the whims and caprices of the visitors. 
Some appoint their associates, friends and family members as vice-chancellors. These appear to have certain effect on the style of administration in such universities. Hence, there is the need for an insight into the effect of politics on university administration in Nigeria.

\section{METHODOLOGY}

The study employed historical research design of descriptive analysis. It utilised mainly secondary dada that were drawn from documents, journals, books, libraries and other relevant sources.

\section{Concept of Politics}

Politics is a phenomenon that generates great deal of apprehension and uneasiness among people all over the world. According to Ogunsanya (1999), politics means partisanship, a game employed to manipulate people and human organisations in the struggle for power. Kansoual (1975) saw politics as dealing with activities and interactions which are closely related to the state and structure of government. Politics are those activities which revolve around decisionmaking functions of the state and involve the concept of power, authority command and control. Lasswell (1936) conceived politics as who gets what, when and how. Eston (1965) posited that politics was concerned with the process of authoritative allocation of scarce values which may be in form of services, goods and money or in terms of formulation of policies on education, health, water among others. Politics is also seen to focus attention on states and its agencies or institutions (Olufemi, 2005). It can be inferred from the above definitions that politics permeates all areas of human lives and endeavours.

According to Hague and Harrop (2013), politics covers a set of activities associated with governing a country, state or an area. It involves decision making which applies to members of groups. Politics refers to achieving and exercising positions of governance which is organized control over human community, especially, a state. Academic study focusing on just policies, therefore, target more than general political science, sometimes referred to as Politology must not be mixed up with Politicology which is a synonym for Political Science (Merriam-Webster, 2018; Native Khabar, 2019). There are formal, semi-formal and formal politics. Formal politics, among others refers to the operation of a constitutional system of government and public institutions and procedures. A lot of people view formal politics as something that is not in them, but can still affect their daily lives. Semi-formal politics is politics in government associations such as neighbourhood associations or students' associations where politics is often practiced. Student Union activities promotes students' success by offering a variety of programmes, serves and facilities which combine to represent well-tailored plan for the development of the school environment (Wing-Yat Yu, 2007; Painter \& Jeffrey, 2009). Informal politics refers to forming alliances, exercising power, protecting and advancing particular ideas. This includes anything affecting people's daily life, such as the way an office or household is managed or how a person or group exercises influence over another. Informal politics is usually seen as every day politics which results to the idea of everywhere politics. However, this paper focused on how politics of the day and political leadership influence day to day administration of Universities.

\section{Concept of Administration}

Administration is a very important aspect of life. Administration is involved in nearly all activities of a government, people or institutions. Administration encompasses policy formulation 
and implementation of an institution. Simon, Smithburg and Thompson (1950) see administration as the activities of groups cooperating to accomplish common goals. As can be seen, administration is defined as cooperative human action or cooperative group behaviour. Human behaviour is cooperative if it has the effect that would be absent if cooperation did not take place. With the same goals in mind, individuals who are specialists in the field of administration come together for the common purpose.

Administration is a cooperative activity mainly concerned with means to achieving an end. According to Waldo (1968), administration is a type of cooperative human efforts that has a high degree of rationality. Olaleye (2006) defines administration as management of men and materials to achieve goals. Balogun (1983) says that administration covers every sphere of activity which can be taken to mean anything ranging from the direction of the affairs of an institution or enterprise to the simple act of paying monthly salaries and pensions. One can therefore say that administration is concerned with organizing personnel or workers, practices/procedures and essential activities that can enhance effective performance of functions which a government of an institution or organisation has assigned itself.

Public administration however, is the implementation of government policy and it's also an academic discipline that studies this implementation and prepares government workers for their job in the public service and institutions (Random House Unabridged Dictionary, 2014). It is a field of enquiry which has a diverse scope with the goal of advancing management and policies so that government can function well. It also refers to as the management of public programmes. It is the translation of policies into reality that people see daily. Public administration is the study of government decision making, the analysis of policies, the various inputs that have produced them and the inputs necessary to produce alternative policies (Denhardt \& Denhardt, 2009; Donald \& Fessler, 2009).

\section{Politics and University Administration}

Politics and administration are two sides of a coin. Both are closely linked. The policies of any government in power politically, socially, educationally, economically, influence the administration of any tertiary institution or university. Many universities workers have expressed their dissatisfaction with the government by going on prolonged strikes due to certain pronouncements and policies of the government in power. The political leadership can, to a significant extent, determine the quality of the leadership of public service and parastatals including tertiary institutions, through the appointment that they make regarding the heads (Yagboyaju and Akinola, 2019). Nigerian political leadership exploited the structural weakness of the country's federalism and its institutions especially tertiary institutions (Akinola and Wissink, 2018). According to Mbah, Nwangwu and Ugwu (2019), political inclusion and national integration have become elusive. In spite of the emphasis of Goal \#10.2 of the 2030 Agenda for sustainable development on political inclusion of everyone, irrespective of race and ethnicity, post-election appointments have been divisive including the appointment of heads of tertiary institutions under Federal and State governments' control.

To Bello, Othman, Khairri and Shariffudin (2017), the political economy of education is influenced by both internal and external actors which included teachers' union, government, bureaucrats, and external officials of international development bodies. These bodies have had certain measures of influence on educational reforms and implementation of educational policies 
in Nigeria. The economic, organisation of education depends largely on the political will of the actors in the political system as well as market mechanism (Adeyemi, and Ayo-Sobowale, (2011). Bello et al (2017) noted that politicians, instead of using education as a piece of development, have turned it to a means of settling political patronage especially with regards to teachers' employment, procurement, contracts for infrastructural development including appointment of Pro-Chancellors, Chairmen of Councils and Vice-Chancellors for Universities and other tertiary institutions. Also, Nigeria has cumulatively invested on average of 8.5 on education as at 2017 of the total budget allocation and Nigeria ranked $20^{\text {th }}$ in the world in allocation to education. World Bank (2012) noted that as at then some countries allocation to education were: Ghana 31\%; Code D Ivoire 30\%; Uganda 27\%; Morocco 26.4\%; South Africa 25.8\%; Swaziland 24.6\%; Mexico 4.3\%; Kenya 23\%; United Arab Emirate 22.5\%; Botswana $10 \%$; Iran 17.7\%; United States of America 17.1\%; Tunisia 17\%; Lesotho 17\%; Burkina Faso 16.8\%; Norway 16.2\%; Columbia 15.7\%; Nicaragua 15\%; India $12.7 \%$ and Nigeria allocated just 8.4\%. According to an Education Minister in the country, since 1999 when democratic governance returned, the annual budgetary allocation to education has been between 4 and 10 percent. Out of Nigerian N8.6 trillion budget in 2017, Nigerians have criticized the government for allocating less than 26 percent that was recommended by UNESCO for education from the national budget of any country. According to a Senate Committee Chairman on Tertiary Institutions and TETFUND in a speech, only N4 billion was actually spent on education in 2017 (Adedigba, 2017).

According to Ogunleye (2015) government policies and practices on implementation of decisions influence or affect how the administrators respond to the development of the University. In the same, in many cases, government policies of States and Federal were not realistic as the involvement of administrators. Olubanji and Akinwande (2019), discovered that low level of attention, inadequate funding, lack of infrastructural facilities to support teaching, learning and research are some among the various problems hindering the successful management of tertiary education in the country. In the same vein, Odu (2010) observed that universities in Nigeria are faced with many challenges and difficulties such as financing, access to staff development, skill based training, quality of teaching, research cum service, relevance of programmes, employability of graduates, inadequate infrastructure and access to information. This has to do with the government of the day and its policies.

The university education has expanded under one government or the other depending on the policies of these governments on education. Ogunleye (2015) revealed that government policies and practices on implementation of decisions influence or affect how the administrators respond to the development of the university. The University of Ibadan was the first university in Nigeria. The university started as the University College, Ibadan in January 1948 on the recommendations of Elliot commission which was set up in 1943. The Ashby Commission set up in 1959 laid the foundation for further expansion of universities in Nigeria. The Ashby Commission report led to the growth in number and student enrolment after the Nigerian independence. According to Seweje and Ayodele (2010), the number of universities in Nigeria increased from 2 at independence in 1960 to 103 by 2010. By 2013 the universities in Nigeria has increased to 174 as evident on Table 1 below. 
Print ISSN: ISSN 2054-6351: Online ISSN: ISSN 2054-636X

\begin{tabular}{|l|l|}
\hline Ownership & Number \\
\hline Federal Government & 43 \\
\hline State Government & 52 \\
\hline Private/Individual & 79 \\
\hline Total & $\mathbf{1 7 4}$ \\
\hline
\end{tabular}

Table 1: Number of Universities in Nigeria as at 2019; Source: NUC 2019 List of Universities in Nigeria (campusbiz.com.ng)

The table shows an impressive increase in number of universities in Nigeria from by 2019. However demand for university education over laps the admission spaces and gaps that universities can fill. For instance, in 2017/2018, 1,840,225 candidates registered for the Unified Tertiary Matriculation Examination (UTME), but only 550,357 got admission, also only 585,498 candidates gained admission into tertiary institutions out of the 1,662,762 applicants that sat for 2018/2019 UTME (Source: www.pulse.ng; www.vanguardngr.com; punchng.com and nigerinscholars.com).

The problem of access to university education is great. This problem is compounded by the Federal Government's Federal Character Policy which stipulates that educational institutions should ensure fair representation of States and Local Governments in admission into schools. This resulted to quota system. The quota system provides equal educational opportunity for applicants seeking admission into public universities. This quota system has paved way for discriminatory cut-off points in favour of candidates from Educationally Less Developed States (ELDS). As a result of this, most qualified candidates from the Educationally Advantaged States are denied admission to universities, whereas candidate from the ELDS, though less qualified, enjoyed university education. This is likely to have inequitable effect on university education while academic merit is being jeopardised and sacrificed on the altar of mediocrity.

The university administration under any political dispensation in Nigeria is saddled with varied challenges. Prominent among these challenges are those that result from the ownership of such universities, the various unions in the universities which borders on strike actions by the union whenever their demands are not met. Some challenges of university education also emanate from student bodies of the universities while some other challenges are caused by certain negligence or the other by the administrative bodies of the universities. The challenges of university administration in Nigeria include financial crisis, deteriorated infrastructures, brain-drain, erosion of university autonomy, and campus cultism crisis from student unionism, high cost of university education, political interference, and high level of examination malpractices, sexual harassment and increasing student population. According to Ibukun (1997), others challenges are the dichotomy between State and Federal Universities, curriculum relevance, quality and the autonomy of universities and strike actions by unions in universities.

Many administrators of universities in the society lack freedom of speech, conscience and prudence to practice autonomy and have generally paid a price for trying to practice these. Some lecturers have been fired for embarking on strike as evident in University of Ilorin before the University union was disbanded. Many lecturers were sacked for being involved in unionism. The case of political interference in university academic decisions is rampant. 
Academic Staff Union of Universities (ASUU) on many occasions serves as checks to governments and other government bodies that are stakeholders in the management and administration of Universities. The Nation (2013) noted that ASUU urged National Universities Commission (NUC) to account for $\mathrm{N} 100 \mathrm{~b}$ stabilisation funds for Universities. ASUU urged relevant anti-graft agencies to probe the NUC. The Union accused the Executive Secretary of NUC of being a clog in the wheel of development of university education in Nigeria. Unionism activities either in the universities or civil and public services were expected to encourage good governance such as transparency, accountability, rule of law, equity, effectiveness, efficiency, responsiveness, strategic and progressive vision, participation in decision-making in their institutions and consensus orientation, adequate funding and staff welfare. Their activities were sometimes misconstrued which led to sanctions from governments on several occasions.

\section{Politics and the Administration of Ekiti State University}

Ekiti State University was established as Obafemi Awolowo University on 30th March, 1982; Ondo State University in 1985; University of Ado Ekiti in November, 1999. The University became Ekiti State University in July 2011 from the erstwhile Universities in Ekiti State namely University of Ado Ekiti (UNAD), University of Science and Technology, Ifaki (USTI) and The University of Education, Ikere-Ekiti (TUNEDIK). According to Ekiti State University (2019), in 2010, there was a change of government in the State and the new government organized a Statewide Education Summit in 2011 to suggest the best way to sustain State owned tertiary institutions and their funding. The Summit recommended the merging of the 3 State-owned Universities into a single one and this was done by law remaining it "Ekiti State University, Ado Ekiti, Nigeria" The National University Commission, Abuja, Nigeria, thereafter, licensed the University and consolidated all assets/records of the Universities as one institution.The University now has 25,000 students, comprising $40 \%$ males and $60 \%$ females $(23,000$ undergraduates and 2,000 postgraduates); 555 academic staff, 1,500, Non-academic staff, 13 faculties, 2 colleges, 4 centres/institutes, 6 affiliate institutions 52 departments and 90 programmes (Ekiti State University, 2019).

The influence of politics on the administration of Ekiti State University, Ado-Ekiti since inception has been great. Accordingly to Benjamin (2001), universities are ivory towers, where instruction is given and received without harassment and undue influence from the outside world. Banjo (2001) also noted that this is in line with the universal idea that the University is a community of scholars, free to pursue knowledge without undue interference from any quarters. Ogunsan (2013) remarked that the influence of politics on the administration of schools may be doing more harm than good to the system. The day undue influence of politics is removed from administration of Universities in Nigeria, is the day the system will start to have an endurable legacy that everyone will be proud of. Politics is one of the problems of universities nowadays. Governors and Presidents have no business administering education. They should invest and let the Governing Councils to administer Universities. They should provide the system with needed funds and allow the universities to operate.

The administration of Ekiti State University has not been left out of the strife to ensure that the goals of tertiary institutions in Nigeria are achieved. In its strife to keep the university going, the university administration had been involved in various activities to fund the institution. Ekiti State University had been funded through government subventions, philanthropic gestures from well-meaning Ekiti indigenes and Nigerians, Education Trust Fund (ETF) interventions, 
donations by corporate bodies, and affiliation relationship with Colleges of Education offering undergraduate courses which earn EKSU revenues annually (The Nation 2013 Tuesday 20th August). The university also had to cope with staff welfare, better salaries and allowances. Whenever the University failed to yield to the request of the staff, it had always resulted in industrial action as witnessed in 2009 (Oyatoye, 2010) and June 2013 before the national ASUU strike.

The various governments in Ekiti State had at one time or the other interfered in the administration of the state-owned university in various ways. The military governments in Ekiti State (between 1996 and 1999) had little or no interference with the administration of the University. The military administrators' challenge then was that of paucity of funds and merely released what they could afford to the University during their regimes. The first civilian government of Ekiti State led by Otunba Niyi Adebayo changed the name of the university from Ondo State University to University of Ado Ekiti (UNAD). The next civilian government of the State led by Mr. Ayo Fayose in his bid at expanding the courses of the University, established College of Medicine in the university. This College of Medicine was scrapped by the third civilian government of Engineer Segun Oni. The Engineer Segun Oni led government, established The University of Education (TUNEDIK) at Ikere Ekiti in the same premises that already housed the state-owned College of Education, and as well run a degree programme in affiliation to University of Nigeria, Nssuka. The same Governor Segun Oni established University of Science and Technology Ifaki-Ekiti (USTI) making three universities in the State that can hardly finance one University. However, immediately the 4th civilian government led by Dr. Kayode Fayemi, assumed office, in its Policy of Consolidation of Education in Ekiti State, merged the two other Universities with UNAD and changed its name to Ekiti State University, Ado-Ekiti (EKSU) (www.eksu.edu.ng ).

Also at the assumption of office by the various State Administrators, the sitting University Chancellors, Governing Councils, Vice Chancellors and Deputy Vice Chancellors of the University have been replaced by every new ones. This had led to drastic changes in the internal administration of the University.

The implication these changes was that the Vice-Chancellors that were relieved of their positions and absolved into EKSU academic staff, lost their huge salaries and other fringe benefits. Besides, the day to day running of the University were impacted either positively or negatively. The University became more populous, which had other implications on accommodation, staffing, funding, programmes and other areas of functioning of the University.

\section{CONCLUSION AND RECOMMENDATIONS}

The interference from owners of universities in their administration spells doom for Universities. The University Governing Councils and the Vice-Chancellors appeared to become puppets in the hands of the Visitors to the Universities be it Federal and State. Many Visitors appointed University Vice-Chancellors as they come. Some appointed their family members, associates and friends as Vice-Chancellors. Appointment of Vice-Chancellors has been politicised and such heads of institutions became tools in the hands of their 'employers'. The freedom of such ViceChancellors and Universities are jeopardised. 
Based on the above, the study recommended that in order to enhance better University administration in Nigeria, interference from political leadership of the owner-government institutions must be reduced. The appointment of Vice-Chancellors must be done according to procedures that are objective. Owners/Visitors of public Universities should not just appoint Vice-Chancellors on the basis of political affiliation or association or friendship. To enhance the desired human development in the University system, government must be ready to support the tertiary institutions with adequate funding and befitting infrastructure. The Universities should also access other means of funding. The administration and Governing Council should be given free hands to run the institutions. Heads of University should be neutral and stay clear of partisan politics. The issue of University autonomy and freedom must be respected in all Universities and tertiary institution. The Universities in Nigeria should guide against any interference from the politics of the day. They should re-order their priorities, be focused and progressive. There is the need for entrepreneurial Universities in the country to enhance their functionality and promote over all sustainable development.

\section{REFERENCES}

Adedigba, A. (2017). Fact check: Did UNESCO ever recommend 26\% budgetary allocation to education? Premium Times. Saturday, December, $9^{\text {th }}$.

Adetunji, A. T. \& Ogunleye, A. K. (2015). The effect of government policies on university administrators: A review of Nigeria. GE International Journal of Management Research. $3(5), 1-55$.

Adeyemi, K. \& Ayo-Sobowale, M. (2011) Funding strategies for quality university education in Nigeria: The principle of fiscal justice. Journal of Studies in Education, 1(1), 1-13.

Akinola, A. O. \& Wissink, H. (2018). Public sector performance in the Nigerian downstream oil sector: A critical reflection. Journal of Asian and African Studies, 53, 476-490.

ASUU (2002). Comment on the bill for universities (miscellaneous) provision act and to make new and better provision for the autonomy management and administration of universities in Nigeria and other matters connected to it. The Guardian. Monday August, 26th; 70-72.

Ayodele, J. B. (2005). Systems analysis in education. Lagos: Bolabay Publications.

Ayodele, O.S., Obafemi, F. N. \& Ebong, F. S. (2013). Challenges facing the achievement of the Nigeria Vision 20:2020. Global Advanced Research Journal of Social Sciences (GARJSS) 2(7), 143-157.

Balogun, M. J. (1983). Public administration in Nigeria: A developmental approach. London: Macmillan.

Banjo, A. (2001). In the saddle: A vice-chancellor's story. In Y. Lebeau \& M. Ogunsanya (eds), The dilemma of post-colonial universities. Ibadan: IFRA/African Book Builders.

Bello, I., Othman, M. F., Khairri, D. \& Shariffuddin, B. (2017). Political economy of education in Nigeria. Asian Journal of Multi-Disciplinary Studies, 5(6), 15-25

Benjamin, S. A. (2001). Perspective on university autonomy and the sustainability of higher education in Nigeria. Proceeding of the 12th General Assembly of the Social Science Academy of Nigeria, 21-28.

Denhardt, R. \& Denhardt, J. (2009). Public administration: An action orientation (6 ${ }^{\text {th }}$ Ed). Belmont C. A: Thomson and Wadsworth.

Donald, K. \& Fessler, J. (2009). The politics of the administrative process. Washington DC; CQ Press.

Easton, D. (1965). A framework for political analysis. Englewood Cliff: Prentice Hall Inc.

Ekiti State University (2013). EKSU at a glance. Lagos: The Rise Print Company. 
Ekiti State University (2019). Brief history. Available online at https://www.eksu.edu .ng. Retrieved January $12^{\text {th }}$.

Hague, R. \& Harrop, M. (2013). Comparative government and politics: An introduction. London: Macmillan.

Ibukun, W. O. (1997). Educational management: Theory and practice. Lagos: GreenLine Publishers.

Kanusoual, G. D. (1975). On government and politics. Belmont: Wadsworth Publishing Co.

Kazeem, Y. (2017). Only in four Nigerians applying to university will get a spot. African Reporter. Available online at https://qz.com/researchgategmbh. Retrieved February, $22^{\text {nd }}$.

Lasswell, H. (1936). Politics: Who gets what, when and how? New York: McGraw-Hall.

Mbah, P. O., Nwangwu, C. \& Ugwu, S. C. (2019). Contentious elections, political exclusion and challenges of national integration. Journal of Cogent Social Sciences, 5(1), 1-21.

Merriam-Webster Dictionary (2018). Definition of politics. Merriamwebster.com. Retrieved February, $25^{\text {th }}$.

Native Khabar (2019). Politics samachar. nativekhabar.com. Retrieved September $24^{\text {th }}$.

Odia, J. \& Odia, A. A. (2020). Accessibility to higher education in Nigeria: The pains, problems and prospects. IGI Global: 80-100. igiglobal.com.

Odia, L. O. \& Omofonmwan, S. I. (2007). Educational system in Nigeria: Problems and prospects. Journal of Social Science, 14, 81-86.

Odu, B. K. (2010). Tertiary education administration for national development. In F. Omotosho, A. A. Agagu \& O. Abegunde (Eds), Governance, politics and policies in Nigeria. Benin Republic: Editions SONOUD' Afrique (ESAF).

Ogunsan, A. (2013). The Nation Newspaper. 1st August.

Ogunsanya, M. (1999). Basic process in education. Oyo: Adeniran Publish Series.

Olaleye, O. O. (2006). Fundamentals of public administration. Lagos: Publishers YPPS.

Olubanji, K. T. \& Akinwande, K. A. (2019). Managing Nigerian tertiary educational institutions successfully: The role of stakeholders.

Olufemi, K. (2005). The role of politics in human (under)development in Nigeria. In D. Kolawole (ed.), Issue in Nigerian government and politics. Ibadan: Dekaal Publishers.

Otuya, S. \& Okolo, P. O. (2020). Leadership and accountability in Nigerian universities: A critical factor for the nation's sustainable development.

Oyatoye, A. T. (2010). Funding of university education in Nigeria. In F. Omotosho, A. A. Agagu \& O. Abegunde (eds), Governance, politics and policies in Nigeria. Benin Republic: Editions SONOUD' Afrique (ESAF).

Painter, J. \& Jeffrey, A. (2019). Political geography: An introduction to space and power. London: Sage.

Random House Unabridged Dictionary (2014). Definition of public administration. Dictionary.infoplease.com. Retrieved $23^{\text {rd }}$ August.

Sanibi, F. A. \& Akpotu, N. E. (2015). The Nigeria education system and Vision 20:2020: A critical development planning perspective. International Journal of Educational Administration and Policy Studies, 7(2), 26-38.

Seweje R. O. \& Ayodele, J. B. (2010). Access to university education. In F. Omotosho, A. A. Agagu \& O. Abegunde (eds) Governance, politics and policies in Nigeria. Benin Republic: Editions SONOUD' Afrique (ESAF).

Simon, H. A.; Smithborg, D. W. \& Thompson, V. A. (1950). Public administration. New York: Alfred A Knopf.

The Nation (2013) Thursday August 1st. 
British Journal of Education

Vol.8, Issue 5, pp.15-25, May 2020

Published by ECRTD- UK

Print ISSN: ISSN 2054-6351: Online ISSN: ISSN 2054-636X

The Nation (2013) Tuesday August 20th.

Waldo, D. (1968). The study of public administration. New York: Random House.

Wing-Yat Yu, E. (2007). Formal and informal politics in Macao Special Administrative Election 2004-2005. Journal of Contemporary China, 16 (52): 417-441.

Yagboyaju, D. A. \& Akinola, A. O. (2019). Nigerian state and the crisis of governance: A critical exposition. Sage Journals. Journalsage.com. 